DOI https://doi.org/10.30525/978-9934-26-114-5-71

\title{
ОЦІНЮВАННЯ ЯК ФУНКЦІЯ УПРАВЛІННЯ ТА МОНІТОРИНГУ ЯКОСТІ ВИЩОЇ ОСВІТИ УКРАЇНИ
}

\author{
Стражнікова I. B. \\ професор кафедри педагогіки та освітнього менеджменту \\ імені Богдана Ступарика \\ Прикарпатський національний університет імені Василя Стефаника \\ Сгорова I. B. \\ доцент кафедри педагогіки та освітнього менеджменту \\ імені Богдана Ступарика \\ Прикарпатський національний університет імені Василя Стефаника \\ м. Івано-Франківськ, Україна
}

Управління - це планомірний вплив на зміст, структуру і передумови ефективності освітнього процесу 3 метою теоретичної та практичної підготовки випускників, спеціалістів, які відповідають сучасним вимогам. Керувати освітнім процесом означає створювати оптимальні зовнішні та внутрішні умови для успішного формування особистості, майбутнього фахівця, раціонально використати різноманітні можливості освітнього процесу, його видів і форм.

Для реалізації функцій керівництва розв'язують такі основні завдання: підбір, розстановка й оцінювання кадрів, постановка завдань перед виконавцями; аналіз та регулювання соціально-психологічного клімату в колективі; стимулювання продуктивної діяльності підлеглих та їх саморозвиток; створення умов для професійного зростання підлеглих.

Освітнє оцінювання - це систематичний опис об'єктів i/або визначення їхньої цінності чи вартості, яке виконує чотири функції: креативну (вдосконалення); підсумкову (вибору і звітності); соціополітичну (мотивації та отримання підтримки громадськості); адміністративну (виявляти владу) [1].

Об'єктом оцінювання може бути будь-хто і будь-що. Типовими об'єктами оцінювання в освітній системі $є$ ті, хто навчається, науковопедагогічний та адміністративний персонал, навчальні плани, директивні матеріали, програми і заклади освіти. Стосовно кожного об’єкта потрібно врахувати чотири величини: його цілі; стратегія i плани; процес впровадження; результати і вплив. 
Для того, щоб визначити цінність або якість освітніх об'єктів, необхідно враховувати такі критерії: відповідність конкретним потребам дійсних і потенційних клієнтів; відповідність національним ідеям, ідеалам, соціальним цінностям; відповідність встановленим стандартам і нормам; перевага над альтернативними об'єктами; досягнення цілей, що ставляться перед об'єктами. Для оцінювання будь-якого об'єкта необхідно використовувати різні критерії, а відтак оцінювання слугує інформаційним потребам потенційних сторін, зацікавлених в об'єктах оцінювання [3, с. 120].

Незалежно від методу дослідження, процес оцінювання повинен охоплювати такі види діяльності: фокусування на проблемі оцінювання; збирання та аналізування емпіричних даних; повідомлення учасникам оцінювання про результати. Ці види діяльності проходять в різній послідовності, що можуть повторюватися декілька разів у процесі оцінювання. Оцінювання має оптимально поєднувати такі стандарти: користь; точність; ймовірність; відповідність.

Педагогічну дійсність можна виміряти (оцінити) через якість i кількість. Якість традиційно розвивається через опис ознак, кількість ототожнюється 3 мірою числом. Оцінити - значить проаналізувати якісний стан об’єкта, кінцевий результат якоїсь діяльності. Застосування комплексної оцінки до всієї освітньої діяльності розпочалося порівняно недавно у зв'язку з атестацією закладів освіти. Значення оцінювання освітньої діяльності полягає передусім у тому, що воно допомагає простежити рівень розвитку освітнього процесу в Україні та регіоні, зокрема. У сучасних наукових дослідженнях оцінювання часто поєднується 3 поняттям «вимірювання», мета якого - отримати інформацію про ознаки об'єктів, їх властивості чи характерні ознаки. Метод вимірювання - певна система фіксації та реєстрації кількісних характеристик досліджуваного об'єкта за допомогою різноманітних вимірювальних засобів.

Науковці стверджують, що, на жаль, жодна 3 відомих систем оцінювання не $\epsilon$ абсолютно досконалою. Тому виділяють критерії якості педагогічних вимірювань:

1. Об'єктивність - оцінювання й адекватність кількісних результатів через максимальну стандартизацію його проведення, доповнюючись об’єктивністю обробки даних та об'єктивністю інтерпретації результатів.

2. Надійність - рівень стійкості результатів, повторюваності їх під час додаткових вимірів у стандартних умовах, ступінь надійності визначається за допомогою коефіцієнта, залежить від об'єктивності методу, параметрів засобу вимірювання, стабільності вимірювальної 
характеристики. Важливою є стабільність характеристики, оскільки ознаки та характеристики в освіті часто лабільні (нестійкі).

3. Валідність - визначається параметрами засобу та процедури його виконання, властивостями досліджуваної ознаки. Висока валідність методу вимірювання - відповідність отриманих даних, водночас його критерій окреслює простір, для якого метод вимірювання дає статистично надійні результати. Для педагогічних вимірювань можна визначити вужчі критеріальні ознаки: валідність змісту, відповідності, прогнозу.

4. Точність методу визначає мінімальну або систематичну помилку, 3 якою можна провести вимірювання цим методом.

Процес оцінювання безпосередньо пов'язаний із такими поняттями, як критерії, показники, параметри. Їх значення полягає в тому, що вони допомагають складні процеси зробити простими; дозволяють порівнювати досягнення навчальних закладів двома способами: у даний момент часу або через певний проміжок часу (синхронна та діахронна перспектива).

Педагогічні вимірювання часто мають на меті отримання даних не лише стосовно конкретної навчальної дисципліни, а й стану, ефективності та якості систем національної освіти. Науковці поділяють ці дані на три великі групи: елементи 3 очевидними кількісними ознаками та вимірами (кількість років навчання, робочих днів, навчальних годин, розв'язаних під час контрольної роботи завдань чи задач, припущених помилок у творі чи диктанті тощо); елементи 3 умовно кількісними характеристиками. У широкому розумінні «ефективність системи освіти» визначається ступенем досягнення поставлених перед нею цілей. У науковій літературі розглядають дві форми ефективності освіти: 1. критерії якості зовнішньої ефективності (розвиток системи освіти на основі використання матеріальних і людських ресурсів, звітність, модернізація освіти на основі потреб ринку праці, створення нових технологія навчання); 2. критерії внутрішньої ефективності освіти в закладі, до яких належать: результативність освітнього процесу; рівень організації освітньої діяльності закладу; додаткові напрями та показники освітньої діяльності, характерні для певного закладу.

На разі, чіткі критерії та показники оцінювання освітньої діяльності навчальних закладів на законодавчому рівні не уніфіковані. Тому в кожному регіоні орієнтовні критерії можуть бути адаптовані до місцевих/регіональних умов шляхом уведення додаткових показників.

Аналіз є невід'ємною функцією управління. Безумовно, без аналізу неможливо дати оцінку якомусь явищу, адже він тісно пов'язаний із 278 
процедурою оцінювання, хоч у теорії менеджменту він виділяється як окрема функція. Аналіз виступає як етап, що передує прийняттю управлінського рішення, пов'язаного 3 оцінюванням. У аналізі визначаються такі операційні дії [3, с. 287]:

- Розкладання інформації на частини може бути реальним i мислячим. Цей етап дуже важливий, бо оцінювати малу інформацію набагато легше, ніж об’ємну. Кількість частин залежить від обсягу інформації і будь-яку інформацію можна дробити на довільну кількість частин.

- Порівняння може бути 3 цілями управління або 3 чимось ідеальним, необхідним, оптимальним, стандартним. Важливо порівнювати не тільки $з$ тим, як повинно бути, а й з тим, як було раніше, що дозволяє побачити позитивні зрушення.

- Узагальнення під час аналізу корисно поєднувати з виділенням головного, суттєвого. Наприклад, можна знати багато причин великої кількості тих, хто навчається з низьким рівнем навчальних досягнень. Проте важливо вміти виділити головні, суттєві причини і на основі них зробити узагальнення, яке передбачає логічний перехід від одиничного до загального, від менш загального до більш загального, до судження, оцінки.

- Абстрагування орієнтує на відмову від конкретних фактів i пошуку науково обгрунтованого алгоритму діяльності. Потім інформація будується відповідно до знайденого алгоритму чи моделі (прикладом можуть бути пам'ятки різного роду, система заходів 3 оптимізації тощо).

- Класифікація - суть полягає в логічному поділі фактів, даних, явищ тощо за якоюсь ознакою, суттєвою для даної групи.

- Систематизація інформації здійснюється на основі виділення в об'єкті спільних ознак.

Таким чином, розвиток експертних оцінок в освіті показує тенденцію до розробки методів, що дозволяють конкретно позначити, визначити, назвати та виміряти результати педагогічної діяльності.

\section{Література:}

1. Алексєєв Н. Г. Принципи і критерії експертизи освіти. Шкільні технології. 2000. № 2. С. 220.

2. Огнев'юк В., Сисоєва С. Підготовка експертів у галузі освіти в Україні. Освітологія. 2015. № 4. С. 54-60.

3. Огнев'юк В. О. Освіта в системі цінностей сталого людського розвитку. Київ: Знання України, 2003. 450 с. 